\title{
Local genetic structure and relatedness in a solitary mammal, Neotoma fuscipes
}

\author{
M. B. McEachern • John M. Eadie • Dirk H. Van Vuren
}

Published online: 4 May 2007

(C) Springer-Verlag 2007

Erratum to: Behav Ecol Sociobiol

DOI 10.1007/s00265-007-0378-2

Due to a publisher's error, this article incorrectly credits the Ecology Graduate Group with authorship. The correct citation of this article is the following:

McEachern MB, Eadie JM, Van Vuren DH (2007) Local genetic structure and relatedness in a solitary mammal, Neotoma fuscipes. Behav Ecol Sociobiol. DOI 10.1007/s00265-0070378-2.

The online version of the original article can be found at http://dx.doi.org/ 10.1007/s00265-007-0378-2

M. B. McEachern $(\bowtie) \cdot J$. M. Eadie • D. H. Van Vuren

Department of Wildlife, Fish, and Conservation Biology,

University of California, Davis,

One Shields Avenue,

Davis, CA 95616, USA

e-mail: mbmceach@gmail.com 